\title{
History of the Uralic languages and the principle of lateral areas*
}

According to a well known claim the lateral parts of a language area preserve linguistic forms better than the interior. The principle of lateral areas was one of the areal norms postulated by the Italian pioneer on language geography Matteo Bartoli in the twenties. Bartoli's norms have since been criticized: they cannot be incautiously applied to the history and especially to the prehistory of a language. However, one of these norms, the norm of lateral areas seems to be more applicable than the others. In fact, it is used as an argument in contemporary studies on language history and language geography, too.

What gives this norm more explanatory power than the others is probably its constancy. This again is due to its geometric nature, which provides a certain independence of more substantial factors. In my contribution, I will deal with some general aspects of the validity of the principle of lateral areas and then present some remarks on its appearance within the Uralic language family.

Obviously the principle of lateral areas is not realized equally in all cases. To what extent an idiom is able to keep old forms and to what extent it tends to change, depends on many other factors besides its geographical position in the periphery or in the interior of the language area. E.g. cultural and social changes, foreign languages and cultures, migrations, activity in social interaction, density of population, areal isolation, and even the norms of written language and conscious language planning are factors which influence the frequency of linguistic changes.

Nevertheless, one can, with good justification, claim that the principle of lateral areas, in conjunction with any other factors, is effective in all cir-

\footnotetext{
* Presented at the Sixth International Congress of Finno-Ugrists in Syktyvkar on 26th July 1985.
} 
cumstances. Even in such extreme cases as when some other factors, e.g. a foreign language, cause a high frequency of changes in the periphery of a language area, there is good reason to assume an opposite effect of the principle of lateral areas moderating the total rate of changes in the idiom. This is based on a simple geometric fact: in general, any point in the interior of a language area receives innovations from all directions round it, at an angle of $360^{\circ}$, whereas the points on the border of a language area are able to receive language internal innovations from certain directions only, i.e. from the interior. Now, the angle is roughly $180^{\circ}$, in general. The effect is striking in an narrow oblong language area. The angle at which innovations come to the end points of the area is always very narrow, in an extreme case they come from one direction only. In a simplified model of the spread of linguistic innovations one can discern a peripheral zone, the points of which receive less language internal innovational waves than any point in the interior. In the course of time the differences between the idioms spoken in the interior and those spoken in the peripheral zone grow, the interior showing more innovations, and the periphery remaining more conservative.

A detailed research into the effect of the lateral area principle in the Uralic languages should be illuminating and could give evidence for reconstructing the historical and prehistorical stages of the development of these languages. In this connection I can point to some illustrative and typical cases only.

Lapp is a textbook example of the effect of the lateral area principle within an oblong language area. The dialects spoken in the two extreme ends of the area, South Lapp in Central Scandinavia and East Lapp dialects, are more conservative than the central dialects. The extreme dialects show archaisms e.g. in consonant quality and in syntax. Besides, morpheme structure and morphology have retained more archaic features in South Lapp than in the other dialects. Isoglosses on the dialect map showing the spread of innovations that have come into existence after the split of Proto-Lapp are most frequent in the area of Central Lapp. Here both Central Lapp innovations and innovations spreading from the east and the south-west overlap, whereas the isoglosses in the South Lapp area principally show south-western and the 
Kola Lapp area eastern innovations only. Only a few Central Lapp innovations have reached South or Kola Lapp.

However, it is remarkable that there are not very many conservative features common to both the extreme dialects. They are archaic in different ways. E.g. they are not mutually intelligible.

In some of the Uralic languages the influence of foreign languages has been so strong that the effect of the lateral area principle is hardly to be seen. In some cases, on the other hand, migrations have changed the earlier geographical relations of dialects so that it is difficult to show which dialects were lateral originally or at least for long enough for the principle of lateral areas to have had an effect on them.

Both these phenomena occur in the Baltic-Finnic language group. According to the present location of these languages, Livonian and Veps are the most lateral idioms of this group. One does indeed find some archaic features in these two languages. Perhaps e.g. the lack of consonant gradation is one of them. I do not mean that the lack as such represents an original state. I rather assume that the original phonetic gradation has become phonemic in the central dialects of Baltic-Finnic but remained unphonemicized in Livonian and Veps. Now, phonemicization could be an innovation of interior dialects that has not reached the lateral ones. The phonetic gradation, having no phonemic function, has disappeared in the lateral dialects, Livonian and Veps, later.

Despite some clear archaic features, Livonian and Veps in general are not conservative. On the contrary, they show perhaps more innovations than any other of the Baltic-Finnic languages. And this is principally due to the very strong foreign influence, Russian on Veps and Lett on Livonian.

What then are the most archaic idioms of the modern Baltic-Finnic languages and dialects? This question is very difficult to answer, because there are no absolute criteria for judging. One dialect shows archaisms in some points, another in some others. However, if one considers the total structure and development of all the Baltic-Finnic languages, very many conservative features are to be found in some West Finnish dialects, especially in those of Häme. This result may be surprising in view of the central location of these dialects among the modern Baltic-Finnic languages. But a look at recent studies of the history of the Finnic languages reveals a very dif- 
ferent picture. The most important component in the development of the Häme dialects seems to have been the Northern Proto-Finnic, which as Terho Itkonen has shown $(1972,1983)$, was spoken north of the Gulf of Finland, in the extreme northern periphery of Baltic-Finnic, for long periods of prehistory. Probably the Häme dialect and its northern Proto-Finnic predecessor was not only peripheral but also more isolated than most of the other Finnic dialects. There are less traces of foreign influence in Häme than in languages spoken south and east of the Gulf of Finland.

South Estonian is another Finnic dialect revealing some very striking archaisms. This is understandable considering its lateral location as the most southern idiom of Baltic-Finnic.

So we find that foreign influence and changes in the geographical relations have partly concealed the effect of the lateral area principle in Baltic-Finnic, but the effect can be discovered in the history and prehistory of this language group.

Let us now proceed to look at the Uralic language family as a whole. For our theme, some well-known aspects in the history of research into the de. velopment of the vowel systems in the Uralic languages are illuminating. Until quite recently the history of Uralic vowels has been approached primarily using a kind of descendent method. Many good results have been achieved. Arvid Genetz published a pioneering study of the history of the Finnish, Lapp and Mordvin vowel systems in 1896. On the basis of Genetz's idea Erkki Itkonen has thoroughly researched the vowel history of all the Finno-Permian languages $(1939,1946,1954)$. As a starting point Itkonen postulated a Proto-Finno-Permian vowel system that resembles the actual Finnish vowel system. The systems of all the Baltic-Finnic languages can be derived from this basic system unambiguously and without gaps in the course of development. The history of the vowels in Lapp and Mordvin becomes quite regular, too, whereas Cheremis and the Permian languages seem to have proceeded further from the starting point, and many sporadic and irregular developments must be assumed.

It was just the opposite extreme that formed the basis of Wolfgang Steinitz's concept of the vowel history of the Finno-Ugrian languages (1944). His reconstruction of the Proto-Finno-Ugrian vowel system is quite similar to the eastern Ostyak Vakh and Vasyugan dialects. The constellation 
is parallel to that of Itkonen in a certain sense. As in Itkonen's system, so in Steinitz's model, too, the explanatory power of the hypothesis is the greater the nearer a language is to the key language, to Finnish in Itkonen's case, and to Vakh-Vasyugan Ostyak in Steinitz's case. Steinitz's model and its later variants are able to explain the vowel history of Ostyak well, and that of the other Ugrian languages satisfactorily, but they are not sufficient to explain the development of the vowel systems in the Finno-Permian languages. We have here two traditions of explanation. One of them is satisfactory for the vowel history of the Finno-Permian branch, but is confronted with many problems when applied to that of the Ugrian branch of the Finno-Ugrian language family. The other again is good for the Ugrian branch, but not suitable for the Finno-Permian branch. Besides, it is not easy to reconcile them.

This disagreement may be confusing if we, in terms of the Finno-Ugrian language family, conclude that both Finnish and East Ostyak are peripheral languages and therefore conservative. In such a case a common starting point should be discovered for the development of these two languages. There is, however, an obvious error on this way of thinking. We have no linguistic, no historical and no geographical grounds for strictly separating the Finno-Ugrian and Samoyed languages from each other. So we have no reason for considering the Finno-Ugrian languages as an independent language stock. We have to deal with the whole Uralic language family. Within this linguistic entity the Finnic and Samoyed languages are lateral, not the Ugrian ones. The predecessor of Finnic and Lapp was located in the western periphery and the predecessor of Samoyed in the eastern periphery of the narrow oblong late Proto-Uralic language continuum. In this model the Ugrian and Permian languages belong to the interior, whereas Mordvin and Cheremis take an intermediate location.

The above geographic-historical model seems to be in harmony with the most recent achievements of the research into Uralic vowel history. Janhunen (1982) after reconstructing the Proto-Samoyedic vowel system compared it with Itkonen's Finno-Permian system and successfully reconstructed the Proto-Uralic system on the basis of these two peripheral systems. In this framework the history of the Finnic, Lapp, Mordvin and Samoyed vowel systems can consequently be explained on the basis of the Proto-Uralic vowel 
system reconstructed by Janhunen, whereas the history of the systems of the interior languages, Cheremis, Permian and especially Ugrian still produce problems.

One can find similar features in the history of morphology, too. The most western and most eastern members of the Uralic language family have common elements and structures that are lacking in the interior languages, e.g. the genitive with the suffix $-n$, the plural with the suffixes $-t$ and $-j$, and some features in the structure of local cases. On the other hand, the interior languages, especially the Ugrian and Permian languages, reveal many morphological innovations. On the basis of lexical correspondences, again, Häkkinen concludes that the strict distinction between the FinnoUgrian and Samoyed language groups is inadequate (1983: 384).

In general, the effect of the lateral area principle is to be seen clearly on the east-west axis of the Uralic language family. Considering the oblong shape of the language area at present, in history and in prehistory, one finds that this is the only natural realization of the principle. Nevertheless, attempts to find traces of archaisms in the southern and northern periphery could give valuable results, whether positive or negative. It is, however, obvious that the possible earlier archaisms of the southern lateral area have disappeared because of strong foreign influence and because of the high frequency of innovations accelerated by just these foreign influences. On the other hand, perhaps the existence of the dual in Lapp, Ob-Ugrian and Samoyed can be interpreted as a relic of northern archaisms.

One must not exaggerate the significance of the lateral area principle: Over the milleria a lot of changes have taken place in the eastern and western peripheries of the Uralic language area, too. These changes have increased the differences between the two poles. It is also natural that the extreme lateral languages have gone through common changes with interior languages spoken in their neighbourhood. So e.g. Baltic-Finnic and Lapp have some innovations in common with Mordvin and Cheremis, and even with the Permian languages, whereas there are some common features between Samoyed and Ugrian, especially Ob-Ugrian. Also the influence of foreign languages has caused changes, the nature of which depends on the structure of the influencing languages, and which have caused the differences between 
the languages affected. Perhaps that is why Baltic-Finnic and Lapp syntactically are so far from Samoyed.

In conclusion, there is evidence for the effect of the lateral area principle in Uralic. This observation may have some methodical value, if applied carefully. E.g. the history of Uralic morphology, and perhaps the history of consonant gradation in Finnic, Lapp and Samoyed is worthy of further research from this point of view. One of the morals of this study is also the emphasizing of the unity of the Uralic language family. Restricting the comparison to Finno-Ugrian alone can cause distorted results.

MIKKO KORHONEN

\section{REFERENCES}

Genetz, Arvid 1896. Ensi tavuun vokaalit suomen, lapin ja mordvan kaksi- ja useampitavuisissa sanoissa. - Vähäisiä kirjelmiä. Helsinki. (Also Suomi III: 13, 1897.)

Häkkinen Kaisa 1983. Suomen kielen vanhimmasta sanastosta ja sen tutkimisesta. - Turun yliopiston suomen ja yleisen kielitieteen laitoksen julkaisuja 17. Turku.

Itkonen, Erkki 1939. Der ostlappische Vokalismus vom qualitativen Standpunkt aus. - MSFOu 79. Helsinki.

- 1946. Zur Frage nach der Entwicklung des Vokalismus der ersten Silbe in den finnisch-ugrischen Sprachen, insbesondere im Mordwinischen. - FUF 29, pp. $222-337$.

- 1954. Zur Geschichte des Vokalismus der ersten Silbe im Tscheremissischen und in den permischen Sprachen. - FUF 31, pp. 149 - 345.

Itkonen, Terho 1972. Historiantakainen Häme ja Suomi kielentutkijan näkökulmasta. - Historiallinen aikakauskirja 1972: 2. pp. 85 - 112.

- 1983. Välikatsaus suomen kielen juuriin. - Virittäjä, pp. 190 - 226, 349 83.

Janhunen, Juha 1982. Uralilaisen kantakielen sanastosta. - JSFOu 77: 9, pp. $219-74$.

Steinitz, Wolfgang 1944. Geschichte des finnisch-ugrischen Vokalismus. Stockholm. 